\title{
INFLUENCE OF CLIMATE ON RADIAL GROWTH OF HOLM OAKS (QUERCUS ILEX SUBSP. BALLOTA DESF) FROM SW SPAIN
}

\author{
DANIEL PATÓN ${ }^{1}$, RICARDO GARCÍA-HERRERA ${ }^{2}$, JAVIER CUENCA1, \\ MAMEN GALAVIS ${ }^{1}$ and FIDEL A. ROIG \\ ${ }^{1}$ Ecology Unit. Faculty of Sciences. Avda. Elvás s/n 06071 Badajoz, Spain. \\ ${ }^{2}$ Department of Atmospheric Physics. Complutense University, 28040 Madrid, Spain. \\ ${ }^{3}$ Laboratory of Dendrochronology. IANIGLA, CCT-CONICET, Mendoza, Argentina.
}

Received 5 January 2009

Accepted 16 September 2009

\begin{abstract}
A total of 47 trunk sections from Holm Oak (Quercus ilex subsp. ballota Desf) trees growing at two different sites at the Extremadura region (SW Spain) were considered in the computation of a regional tree-ring chronology useful to interpret the tree-ring/Mediterranean climate relationships. This is the first dendroclimatological research of Holm Oaks conducted to reveal its potential use as a climatic proxy. The obtained tree-ring chronologies were compared with climatic parameters based on monthly, seasonal and annual rainfall, and monthly maximum, minimum and average temperature. The best correlations were obtained with maximum temperatures during the period between previous winter and early spring. Influence of rainfall was less relevant. Growth of this species indicates a typical bimodal (spring and autumn) strategy that avoids low winter temperatures and summer drought. Despite some technical difficulties recognizing tree rings in Holm Oaks, its good sensitivity to climate variability and its wide distribution and longevity ( $\sim 800$ years), allow us to consider this species as a good candidate for temperature reconstructions in the Mediterranean Basin.
\end{abstract}

Keywords: Quercus ilex, dendrochronology, dendroclimatology, tree rings, maximum temperature, climatic change, Extremadura, Spain.

\section{INTRODUCTION}

Tree rings have been used extensively in temperate regions to reconstruct forest responses to past environmental changes. In the western area of the Mediterranean Basin, dendrochronological studies are scarce when compared with other areas of Europe (Patón et al., 1993; 1998; 2006a; 2006b; 2006c; Caritat et al., 1996; 2000; Nabais et al., 1998-1999; Costa et al., 2001). However, the analysis of tree rings is important to understand and predict the effects of climate change and desertification consequences (Meko et al., 1995; Le Houérou, 1996; Puigdefábregas and Mendizábal, 1998; Touchan and Hughes, 1999). Therefore, it is urgent to find climate proxies widely distributed along the Mediterranean Europe that allow us to extend the knowledge of the past climate (Serre-Bachet et al., 1992; Glueck and Stockton,

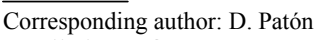

e-mail: dpaton@unex.es
2001; García-Herrera et al., 2007). Different tree species from Mediterranean Europe have been used in dendroclimatic studies but, at present, scarce information from Holm Oak (Quercus ilex subsp. ballota Desf) exists. Holm Oak is a drought-tolerant species (Martínez-Vilalta et al., 2002) widely distributed in the Mediterranean Basin where approximately $60 \%$ of this kind of forest (commonly named "dehesa") is located in Spain. From a total coverage of $2,889,341$ ha in the Mediterranean basin, 831,000 ha are present in the Extremadura region (Corcuera et al., 2004). In this area, the Holm Oak forests represent $74.82 \%$ of the total forest surface, where the rest is vegetated by other Mediterranean Quercus species such as Cork Oak (Quercus suber L.), Pyrenean Oak (Quercus pyrenaica Willd.), Portuguese Oak (Quercus faginea Lam.), Kermes Oak (Quercus coccifera L.), and other tree species such as Sweet Chesnut (Castanea sativa L.), Maritime Pine (Pinus pinaster Ait), Stone Pine (Pinus pinea L.) or river forests with Willow (Salix spp.), Black Alder (Alnus glutinosa L.) and Narrow-leafed Ash 
(Fraxinus angustifolia Vahl.). Holm Oak can be found along a wide altitudinal range (0-2,000 $\mathrm{m}$ a.s.1.), although the majority of the forest stands appear between 400$1,200 \mathrm{~m}$ a.s.l, both on siliceous and calcareous soils. Holm Oaks need a minimum rainfall of $100 \mathrm{~mm}$, with an optimum of $600 \mathrm{~mm}$ but can also be located in areas with $800 \mathrm{~mm}$ of rainfall given mixed forests on sunny slopes. Different botanical and phytogeographical studies indicate that Holm Oak includes two subspecies different in morphology and distribution. They are $Q$. ilex L. subsp. ilex, restricted to mild, coastal areas from Greece to France, and Q. ilex L. subsp. ballota (Desf.) Samp., dominant in continental sites in Spain and N. Africa (Saenz, 1967; Tutin et al., 1993; Blanco et al., 1997). Lumaret et al. (2002) indicates that the early genetic differentiation between both subspecies was caused by the contrasting climatic conditions of their distinct geographical areas. Average temperature requirements of Holm Oak vary between $10^{\circ} \mathrm{C}$ in winter and $25^{\circ} \mathrm{C}$ in summer.

Certain studies indicate that Quercus ilex and Quercus suber forests are decreasing in surface and viability during recent decades due to insect damage, fungal diseases, overgrazing, overbrowsing and inadequate forest management practices (Patón et al., 1999; Pulido et al., 2001; Rodríguez et al., 2003; 2005; Plieninger et al., 2004;
Martín et al., 2005). Also, there is evidence of spring rainfall reduction and increase in winter temperatures in Western Iberia in the last forty years (Del Rio et al., 2004; Paredes et al., 2006; Serrano et al., 1998). These effects increase the water stress on Mediterranean forests during spring and thus their vulnerability to different fungal and insect diseases in winter (Hódar et al., 2003; Puerto and Rico 1989). Therefore it is very important to define the degree of influence of rainfall and temperature on Holm Oak tree rings, not only for ecological purposes but also to interpret the past climate variability from their tree rings. Despite the importance of Holm Oak in the economy and environment of SW Spain, no dendroclimatological studies have been carried out with old trees of this species. Only certain studies demonstrate the incidence of water deficit in radial growth of stems, root sprouts, branches or in young trees (Corcuera et al., 2004; Cherubini et al., 2003). Our study is the first one searching the relations between climate and radial growth by dendroclimatic techniques in adult Holm Oak trees. In the present paper, we assess a methodology for the recognition of tree rings in this species and the response of Holm Oak tree rings to climate. We use non-parametric correlation analysis to detect the influence of 68 climatic parameters on radial growth. We suspect that the decrease of spring rainfall and increase in temperatures detected
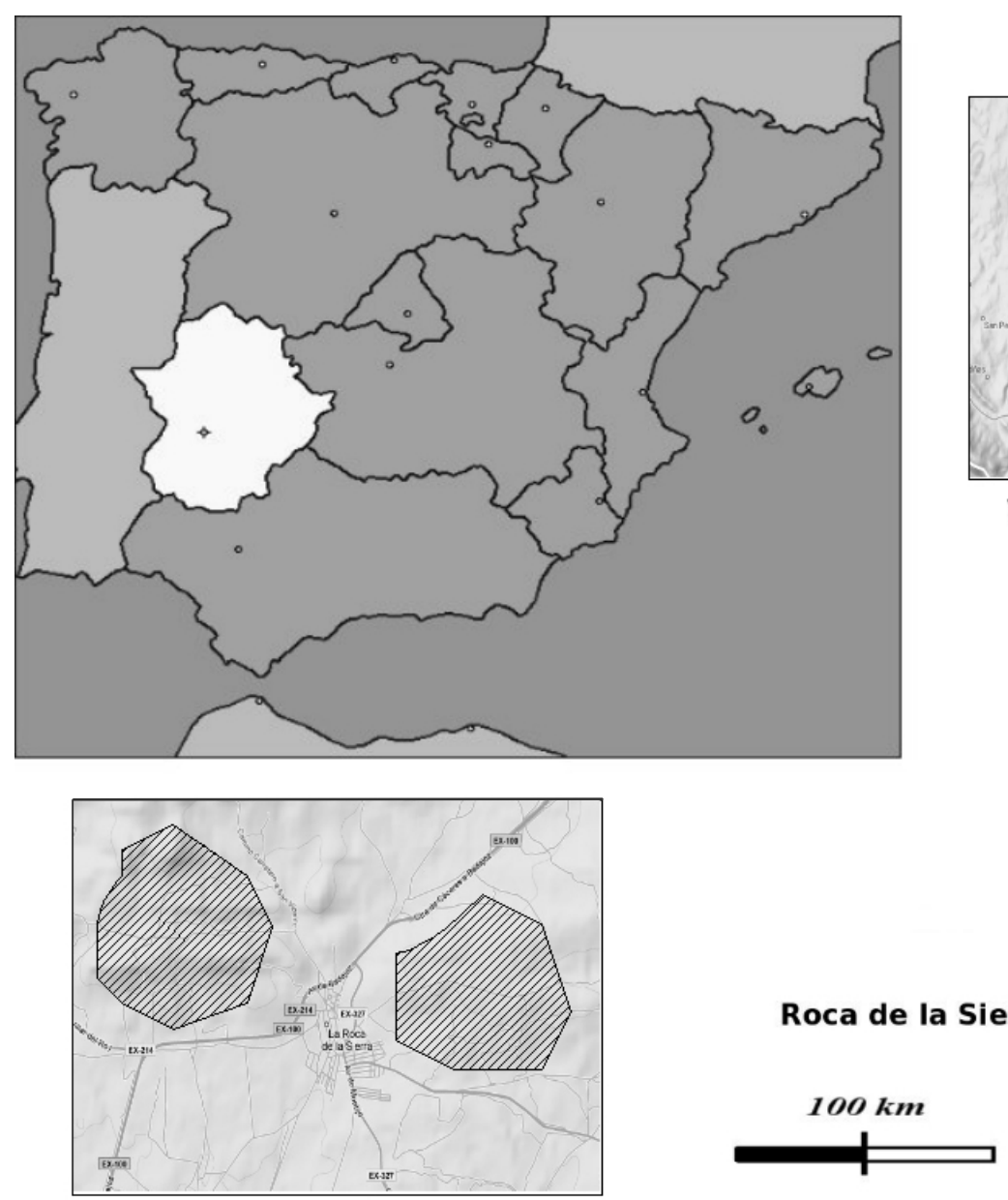

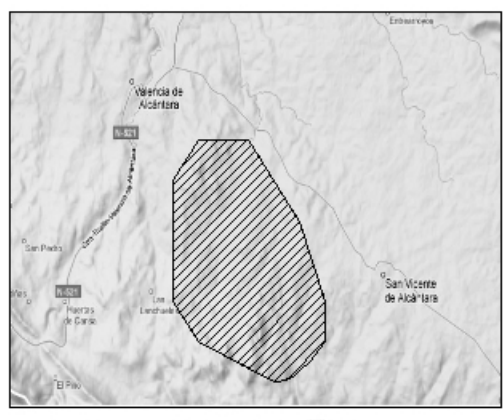

Valencia de Alcántara

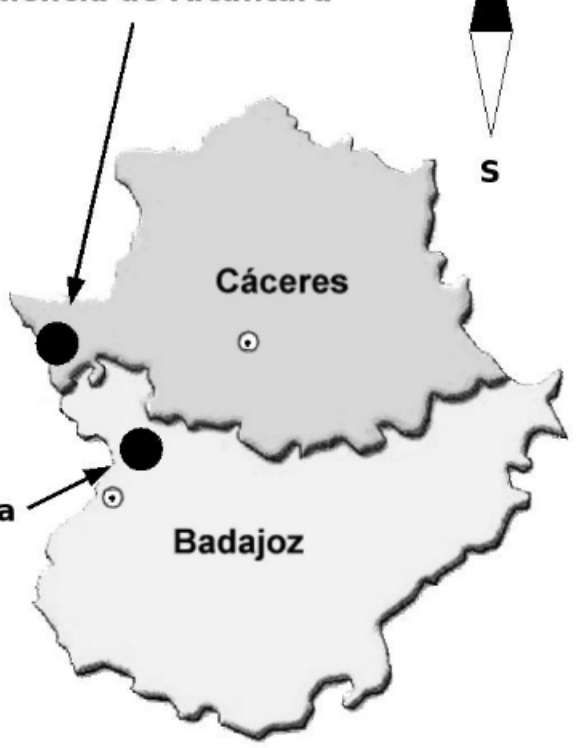

Fig. 1. Location of the two sampling areas in Western of Extremadura Region (SW Spain). 
from instrumental records and from our tree-ring analysis, might seriously compromise the survival of the main Mediterranean forest in SW Spain.

\section{MATERIAL AND METHODS}

\section{Study area}

The study area is located in the southwestern Iberian Peninsula. Two Holm Oak stands separated from each other by $50 \mathrm{~km}$ were selected for the dendrochronological sampling: "Roca de la Sierra" (BA, Spain - 3906'N, $6^{\circ} 41$ 'W, $248 \mathrm{~m}$ a.s.1.) and "Valencia de Alcántara" (CC, Spain - 39 $24^{\prime} \mathrm{N}, 7^{\circ} 14^{\prime} \mathrm{W}, 461 \mathrm{~m}$ a.s.1.) (Fig. 1). The annual rainfall for the area is $623.9 \mathrm{~mm}$ and the mean annual temperature is $16.4^{\circ} \mathrm{C}$ with daily records ranging in the instrumental period between a daily maximum of $44^{\circ} \mathrm{C}$ in July and a daily minimum of $-3^{\circ} \mathrm{C}$ in January. The dry season usually occurs from May to September and precipitation is concentrated from October to April. This climatic information corresponds to the average of the two weather stations, "Roca de la Sierra" and "Valencia de Alcántara", during the period between 1950 and 2007 (Fig. 2).

The predominant soils in the area are identified as dystri-endoleptic, dystri-epileptic and dystric Cambisols. The texture is clay loam to sandy clay loam with clay content higher than $8 \%$. The organic matter content oscillates between $1-2 \%$ and the CIC is between $16-25 \mathrm{cmol}_{(+)} \mathrm{kg}^{-1}$. The base saturation is close to $63 \%$ and the $\mathrm{pH}$ oscillates between 5.5-6.0, although the acidity decreases with depth. Soil moisture shows great fluctuations during the year in agreement with meteorological data.

The potential vegetation corresponds to a mixed Mediterranean sclerophyllous forest dominated by Holm Oak (Quercus ilex subsp. ballota Desf) and Cork Oak (Quercus suber L.) trees with shrublands composed by Cistus salvifolius L., Cistus ladanifer L., Genista hirsuta Vahl, Lavandula stoechas L. and Phillyrea angustifolia L. The sampling area is exploited under the traditional "dehesa" management, usually based on an agro- silvopastoral system where Holm Oaks are used for acorn production and Cork Oaks for cork extraction (Olea and San Miguel, 2006). The herbaceous layer is used for grazing and certain pasture improvement based on tillage and phosphoric fertilization is only applied in the population of "Roca de la Sierra" (Badajoz province). The "Valencia de Alcántara" population presents a light forest management based in occasional and moderate pruning.

\section{Sampling procedure}

In the present study we worked with 47 trunk sections obtained at DBH (Diameter at Breadth Height) from two populations: Roca de la Sierra $(n=31)$ and Valencia de Alcántara $(\mathrm{n}=16)$ (Fig. 1). These samples were obtained from Holm Oaks cleared by road constructions or trees killed by the forest fires that destroyed 25,836 ha from Spain and Portugal during the very hot summer of 2003 (González et al., 2007). The trees were selected inside the sampling areas by its larger trunk size and right growth habits (Fig. 1). Both sampling areas are close to climatic stations and showed similar ombroclimatic diagrams (Fig. 2). Climatic information was obtained from the Spanish National Institute of Climatology in Badajoz (Spain) covering 48 and 62 years for "Valencia de Alcántara" and "Roca de la Sierra" stations respectively. In the laboratory the samples were polished firstly with a Virutex LB31E belt sander using sandpaper of grain size of $60,80,120$ and 250 and finishing with orbital sander Black\&Decker KA190E using sandpaper up to grain size 400, 800 and 1200. The different sections were scanned to very high resolutions (9600 dpi) and ring widths were measured with CAD Software (Q-CAD) using a Debian GNU Linux operating system. Due to the sinusoidal form of the tree ring boundaries (Fig. 3) and the possible influence of this factor on measuring and cross-dating steps, we performed four radial measurements for each trunk section that were averaged for each one of the 47 trees and finally only a single series by tree was used in intertree comparisons and average (Patón et al., 2006b).
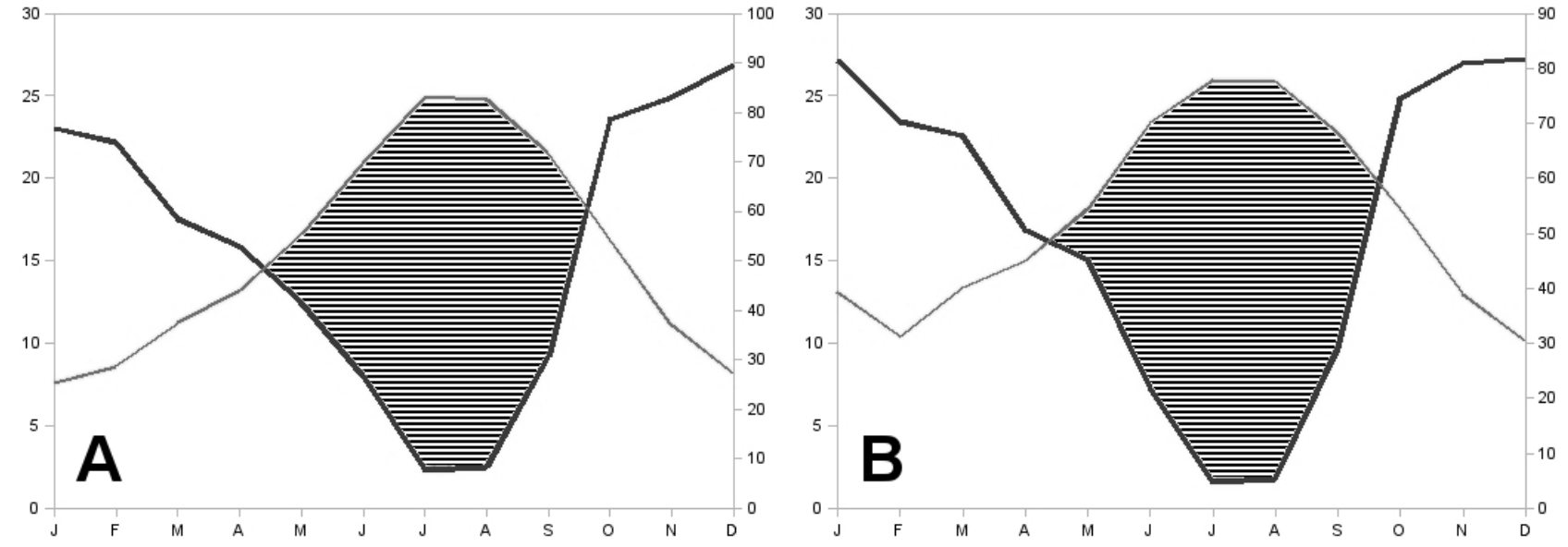

Fig. 2. Ombroclimatic diagrams for Valencia de Alcántara (A) and Roca de la Sierra (B) in Extremadura region (SW Spain). 


\section{Statistical analysis}

Data quality was validated using the computer program COFECHA (Holmes, 1983). To compute the ring width index chronology, the computer program ARSTAN was used (Cook, 1985). The common signal strength in the series was determined by RBAR (Wigley et al., 1984). RBAR is defined as the average correlation between all the series, which is an expression of the percentage variance in common. We estimated another statistics, the expressed population signal (EPS), that express the relationships between a finite sample chronology and the theoretical population chronology (Wigley et $a l, 1984)$. EPS is very dependent on the number of trees used in the chronology and according to Wigley et al (1984) its value must be above 0.85 . The raw ring-width data was standardized to remove growth rate due to agerelated trends and particular differences among trees. According to this principle, a cubic smoothing 32-year spline with a $50 \%$ frequency response is fitted to the measured ring-width time series. The use of this spline stiffness flexibility minimizes the non-climatic variances attributed to increasing age, tree size, grazing, pruning intensity, density and changes in the supply of soil nutrients (Fritts, 1976; Cook and Kairiukstis, 1990). Both final standard and residual chronologies were tested against the 68 climatic parameters using a Spearman rank correlation index. The climatic parameters were monthly, seasonal and annual rainfall, maximum, average and minimum temperatures. The fitting of the tree-ring series against climate was performed by an Artificial Neural Network (ANN). Helama et al., 2009 find similar behaviour of ANN to Multiple Linear Regression for Lapland trees. However, Carrer and Urbinati (2001) obtain better results in the description of the modal relationships between temperature and radial growth of different tree species in the Alps. In our opinion, ANN is a very good procedure that permits analyzing the optimum of climate-growth relationships. All the statistical analysis was made with the STATS and NNET programs under R environment in a Debian GNU Linux workstation (R Development Core Team, 2003).

\section{RESULTS}

\section{Distinction of Tree Rings}

Holm Oak is a ring to semi-diffuse-porous wood with multiseriate rays that can disturb the fine distinction of the tree ring boundaries (Fig. 3). These rings can be accurately recognized only after a very careful polishing with the finest sandpapers. An additional problem with this species is the sinusoidal tangential form of the tree ring boundary that produces a variable distance between rays (Fig. 3). In order to solve these problems we measured four rays per tree. The studies of Corcuera et al. (2004), using branches and root sprouts, demonstrate that this species forms false rings as a consequence of the typical variability of Mediterranean climate, associated to precipitation variability during late summer or early autumn. False rings are produced when July-August rainfall is low and September-October is higher. These conditions have been more frequently produced during the last decades

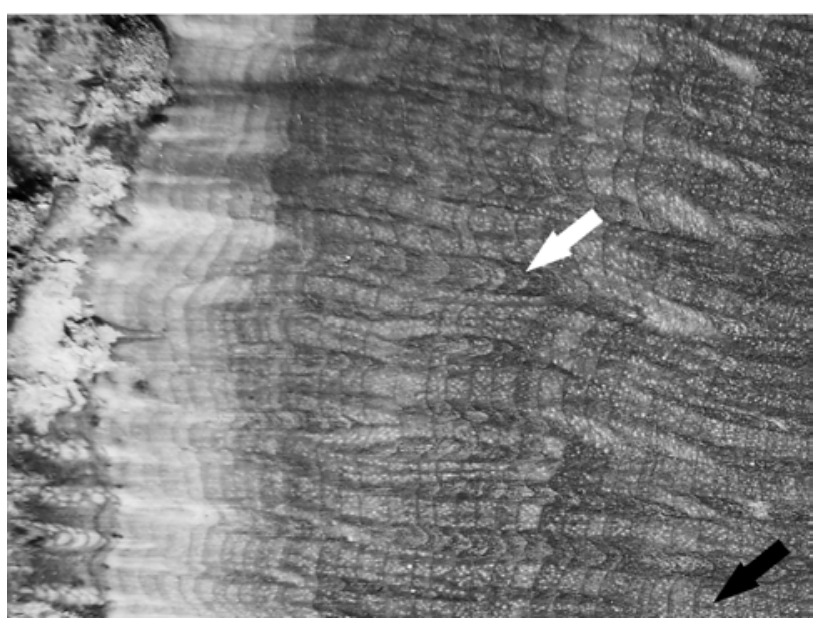

Fig. 3. Visualization of tree rings in Holm Oak (Quercus ilex subsp. ballota Desf). Medullar radius (white arrow) and false rings (black arrow) can be observed.

and only affect certain trees. In consequence, false rings were easily detected by crossdating. Another problem was the extremely narrow rings of the external area of the oldest trees. To solve this problem, we increased the sample size with young trees which present wider rings that were easier to measure.

\section{Cross-dating}

Initial trials with this species gave poor cross-dating results using graphical and statistical techniques. Only after four radii per section were used, false rings and other dating mistakes were easily detected (Fig. 3). Also, cross-dating comparison between the different site populations were determinant in the dating quality control due to the marked microclimate differences between these sites. In particular, the population of "Roca de La Sierra" (Badajoz) showed more intense short-time perturbations by livestock and pruning, a factor that undoubtedly may affect cross-dating. In contrast, the population of "Valencia de Alcántara" (Cáceres) experienced a very low level of pruning. This population shows a higher frequency of late summer storms that has been related to a higher incidence of false rings (Corcuera et al., 2004). In contrast, the population of Badajoz Province shows a lower incidence of the late summer storms, and probably a lower incidence of false rings. Missing rings were $0.38 \%$ and $0.07 \%$ respectively for both populations. The correlation matrix computed using all the trees of both populations,

Table 1. Results of COFECHA program for populations of "Valencia de Alcantara" (VA), "Roca de la Sierra" (RS) and both.

\begin{tabular}{lccc}
\hline Parameter & VA & RS & Both \\
\hline Number of trees (series) & $16(32)$ & $31(72)$ & $47(104)$ \\
\hline $\begin{array}{l}\text { Number of years } \\
\text { master series }\end{array}$ & 78 & 247 & 248 \\
\hline Total rings in all series & 1047 & 2526 & 4599 \\
\hline Total dated rings checked & 1045 & 2522 & 4597 \\
\hline Series intercorrelation & 0.57 & 0.52 & 0.54 \\
\hline Average mean sensitivity & 0.20 & 0.37 & 0.32 \\
\hline
\end{tabular}




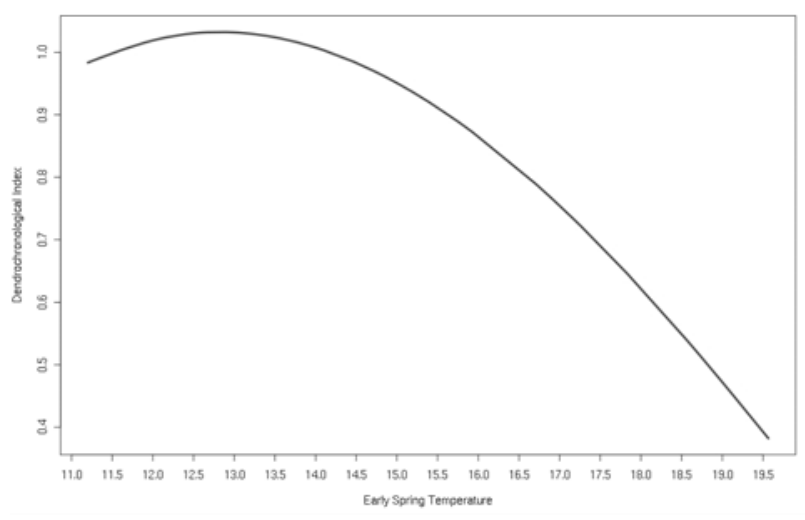

Fig. 4. Artificial Neural Network Response function of dendrochronological index in regard to average maximum temperature in the period between late winter and early spring.

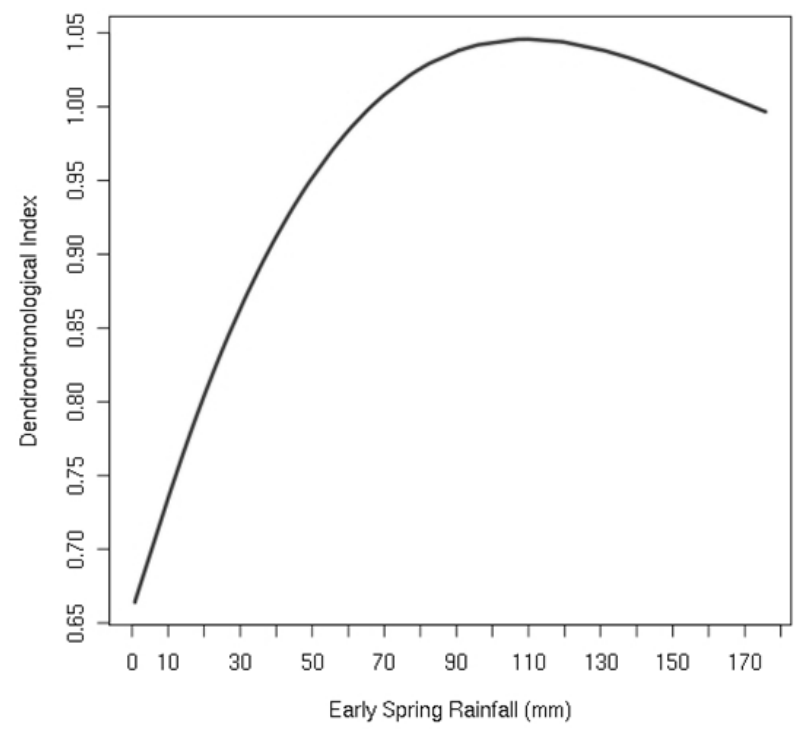

Fig. 5. Artificial Neural Network Response function of dendrochronological index in regard to early spring rainfall in the period between late winter and early spring.

indicates an average correlation of 0.54 (significant at $\mathrm{p}<0.05$ ) between individual tree ring-width time series and a mean sensitivity of 0.32 (Table 1). These values are certainly higher compared with data obtained from other Mediterranean species (Cherubini et al., 2003).
RBAR for "Alcantara" and "Roca" populations were 0.174 and 0.119 respectively. However, the joined analysis of both populations give a value of 0.229 . EPS for "Alcantara" and "Roca" populations were 0.769 and 0.745 under the critical value of 0.85 (Wigley et al. 1984). The analysis of joined effect of both populations show a value of 0.864 over the critical value and very similar to results obtained by Roig et al. (2009) with Sweet Chesnut (Castanea sativa Miller) in the North of Extremadura region.

\section{Determination of Standard and Residual series}

The statistics values obtained from ARSTAN indicates good performance (Tables 2), although worse than for other Mediterranean species such as those belonging to the genus Pinus, Castanea or Quercus (Tardif and Conciatori, 2006; Patón et al., 2006c). The non-perturbed population of "Valencia de Alcantara", located in a mountainous area far of the optimum niche of this species, showed the higher values of the signal to noise ratio and agreement with population chronology (Table 2). In contrast, the "Roca de La Sierra" population presents higher values of the mean sensitivity and variance in the first eigenvector (Table 2). When tree-ring series from both populations are mixed (Table 2 , the variance due to the first eigenvector increases while the values of the other parameters decrease. Consequently we use both populations for independent comparisons with climate. Despite the high inter tree variability in growth, genetics, physiology, acorn production or even acorn composition (Corcuera et al., 2002; Cañellas et al., 2007; Moreno and Cubera, 2008), Holm Oak is a good climate indicator.

\section{Comparisons between tree rings and climate}

Table 5 shows the results of Spearman rank correlation tests on monthly, seasonal and annual rainfall and maximum, minimum and average temperatures. Results show a slight influence of spring, winter and autumn rainfall on tree ring widths. Regarding temperatures, the best correlation was obtained by comparison of tree growth with January maximum temperature (Table 3 ). Using an Artificial Neural Network (ANN) analysis, we explored the influence of air temperatures in the seasonal growth ring formation of Holm Oak trees (Fig. 4). This analysis also shows that the maximum growth in this species is obtained at around $13^{\circ} \mathrm{C}$ of average maximum air temperature during January, February and March, and decreases markedly with temperatures over $16^{\circ} \mathrm{C}$ during

Table 2. Parameters of ARSTAN program for Standard and Residual chronologies for populations of "Valencia de Alcantara" (VA), "Roca de la Sier (RS) and both.

\begin{tabular}{|c|c|c|c|c|c|c|}
\hline \multirow[b]{2}{*}{ Parameter } & \multicolumn{3}{|c|}{ Standard } & \multicolumn{3}{|c|}{ Residual } \\
\hline & VA & RS & Both & VA & RS & Both \\
\hline Mean sensitivity & 0.14 & 0.23 & 0.16 & 0.11 & 0.26 & 0.18 \\
\hline Common interval mean and standard deviation & $1.00 \pm 0.17$ & $0.97 \pm 0.18$ & $0.96 \pm 0.17$ & $0.99 \pm 0.11$ & $0.98 \pm 0.17$ & $0.97 \pm 0.16$ \\
\hline Skewness & 0.49 & 0.27 & -0.41 & -2.27 & -0.07 & -0.29 \\
\hline Kurtosis & 3.50 & 2.58 & 1.73 & 8.45 & 2.69 & 2.74 \\
\hline Autocorrelation first-order & 0.27 & 0.27 & 0.23 & 0.01 & -0.08 & 0.01 \\
\hline Signal to noise ratio & 10.63 & 4.88 & 3.24 & 11.04 & 5.01 & 3.42 \\
\hline Agreement with population chronology & 0.91 & 0.83 & 0.76 & 0.92 & 0.83 & 0.77 \\
\hline Variance in first eigenvector & $26.22 \%$ & $28.61 \%$ & $29.41 \%$ & $26.42 \%$ & $25.89 \%$ & $29.66 \%$ \\
\hline
\end{tabular}


Table 3. Correlations between monthly, seasonal and annual rainfall $(P)$, average $(T)$, maximum $(T M)$ and minimum temperature $(T m)$ with Standé and Residual chronologies.

\begin{tabular}{|c|c|c|c|c|c|c|c|c|}
\hline & Standard & & & & Residual & & & \\
\hline & $\mathbf{P}$ & $T$ & TM & $\mathrm{Tm}$ & $P$ & $\mathrm{~T}$ & TM & $\mathrm{Tm}$ \\
\hline January & $0.08 \mathrm{~ns}$ & $-0.33^{*}$ & $-0.53^{* * *}$ & $-0.02 \mathrm{~ns}$ & $0.06 \mathrm{~ns}$ & $-0.12 n s$ & -0.28 * & $0.08 \mathrm{~ns}$ \\
\hline February & 0.31 * & -0.28 * & $-0.32 *$ & $0.15 \mathrm{~ns}$ & 0.34 * & $-0.19 n s$ & -0.33 * & 0.29 * \\
\hline March & $0.34^{* *}$ & $-0.35^{* *}$ & $-0.41^{* *}$ & 0.13 ns & 0.38 ** & $-0.11 \mathrm{~ns}$ & $-0.25 \mathrm{~ns}$ & $0.35^{* *}$ \\
\hline April & $-0.09 \mathrm{~ns}$ & $-0.17 \mathrm{~ns}$ & $-0.20 \mathrm{~ns}$ & $0.21 \mathrm{~ns}$ & $-0.05 \mathrm{~ns}$ & $-0.06 \mathrm{~ns}$ & $-0.08 \mathrm{~ns}$ & $0.19 \mathrm{~ns}$ \\
\hline May & $-0.27^{*}$ & $-0.02 n s$ & $-0.08 \mathrm{~ns}$ & $0.22 \mathrm{~ns}$ & $-0.30 *$ & $0.06 \mathrm{~ns}$ & $-0.00 \mathrm{~ns}$ & $0.27^{*}$ \\
\hline June & $0.01 \mathrm{~ns}$ & $-0.27^{*}$ & $-0.34^{* *}$ & $0.09 \mathrm{~ns}$ & $-0.11 \mathrm{~ns}$ & $-0.07 \mathrm{~ns}$ & $-0.12 \mathrm{~ns}$ & $0.11 \mathrm{~ns}$ \\
\hline July & $-0.00 \mathrm{~ns}$ & $-0.09 \mathrm{~ns}$ & $-0.33^{*}$ & $0.55^{* * *}$ & $-0.20 \mathrm{~ns}$ & $0.06 \mathrm{~ns}$ & $-0.11 \mathrm{~ns}$ & $0.45^{* * *}$ \\
\hline August & $-0.16 \mathrm{~ns}$ & $-0.05 \mathrm{~ns}$ & $-0.16 \mathrm{~ns}$ & $0.22 \mathrm{~ns}$ & -0.23 ns & $0.02 \mathrm{~ns}$ & $-0.13 \mathrm{~ns}$ & $0.25 \mathrm{~ns}$ \\
\hline September & $-0.10 \mathrm{~ns}$ & $-0.10 \mathrm{~ns}$ & $-0.18 n s$ & $-0.01 \mathrm{~ns}$ & $0.00 \mathrm{~ns}$ & $-0.06 n s$ & $-0.20 \mathrm{~ns}$ & $0.04 \mathrm{~ns}$ \\
\hline October & -0.06 ns & $-0.29 *$ & $-0.20 \mathrm{~ns}$ & $-0.08 \mathrm{~ns}$ & $-0.09 \mathrm{~ns}$ & $-0.15 \mathrm{~ns}$ & $-0.19 \mathrm{~ns}$ & $0.04 \mathrm{~ns}$ \\
\hline November & -0.28 * & $-0.18 n s$ & $-0.25 n s$ & $-0.14 n s$ & $-0.20 \mathrm{~ns}$ & $-0.08 n s$ & $-0.02 n s$ & $-0.14 n s$ \\
\hline December & $-0.03 n s$ & -0.26 * & $-0.16 \mathrm{~ns}$ & $-0.16 \mathrm{~ns}$ & 0.02 ns & -0.02 ns & $0.08 \mathrm{~ns}$ & $-0.08 \mathrm{~ns}$ \\
\hline Spring & $-0.01 n s$ & $-0.18 n s$ & $-0.23 n s$ & $0.23 \mathrm{~ns}$ & $0.11 \mathrm{~ns}$ & $0.01 \mathrm{~ns}$ & $-0.11 \mathrm{~ns}$ & 0.31 * \\
\hline Summer & $-0,02$ ns & $-0.20 \mathrm{~ns}$ & $-0.37^{* *}$ & 0.38 ** & $-0.22 \mathrm{~ns}$ & $-0.01 \mathrm{~ns}$ & -0.14 ns & 0.38 ** \\
\hline Autumn & -0.28 * & -0.29 * & $-0.30 *$ & $0.10 \mathrm{~ns}$ & $-0.23 \mathrm{~ns}$ & $-0.16 n s$ & $-0.18 n s$ & $-0.00 \mathrm{~ns}$ \\
\hline Winter & $0.11 \mathrm{~ns}$ & -0.38 ** & $-0.46^{* * *}$ & $-0.04 \mathrm{~ns}$ & $0.20 \mathrm{~ns}$ & $-0.13 n s$ & $-0.23 n s$ & $0.13 \mathrm{~ns}$ \\
\hline Annual & -0.16 ns & -0.28 * & $-0.44^{* * *}$ & $0.17 \mathrm{~ns}$ & $-0.11 n s$ & $-0.04 n s$ & $-0.22 n s$ & $0.26 \mathrm{~ns}$ \\
\hline
\end{tabular}

the same months. Considering rainfall data in the ANN analysis, we found that the maximum growth in Holm Oak trees is obtained at the level of $110 \mathrm{~mm}$ of rainfall fallen during February and March (Fig. 5).

\section{DISCUSSION}

Although a suite of dendrochronological studies under the Mediterranean climate indicates that several species are useful for ecological and paleoclimate research (Roig et al., 2006), the present paper indicates that Holm Oak is a valuable tree species for dendrochronological research in south western Iberia, one of the critical rainfall fluctuation regions of Europe linked to the North Atlantic Oscillation variability (Trigo et al., 2006). Holm Oak is a tree species with a ring-to-diffuse porous wood structure, that suggests an adaptation to drought conditions (Zhang and Romane, 1991; Terradas and Savé, 1992; Villar et al., 1997; Terradas, 1999; Corcuera et al., 2004). However, this structure produces difficulties in the identification of tree ring boundary. In the Extremadura region, pruning and grazing activities on Holm oaks forest are extended practices used to improve the tree productivity. This fact may introduce modifications in tree ring values by factors other than the influence of climate and consequently may lower the common growth pattern necessary for successful cross-dating and growth-climate comparisons. In order to avoid these problems, we sampled in areas with low incidence of these management practices such as the region of "Valencia de Alcántara" in Eastern Extremadura. According to the present results, the Holm Oak trees demonstrate to be a good candidate to extend the dendrochronological studies in Mediterranean areas of Spain. However, for climatic reconstruction RBAR, very dependent on sample size, is slightly low indicating the necessity of increase sampling size to more populations and trees. Holm oaks present a high longevity compared with other tree species of the genus Quercus and shows a wide distribution due to its high adaptability and ecological valence (Panaïtois et al., 1997; Nardini et al., 2000; Pañuelas et al., 2000; 2001; Ogaya et al., 2003). Moreover, the sensitive response of Holm Oak growth to climate variability places this tree species as a potential high-resolution climate proxy from southern Europe and northern Africa (Luterbacher et al., 2006 and references therein, García-Herrera et al., 2007). According to the IPCC fourth Assessment (Meehl et al., 2007), the annual precipitation and number of precipitation days are decreasing in the Mediterranean Basin. At seasonal scales, the decrease should be higher (around 40 per cent) in the summer precipitation than during the winter, which could be reduced 10-15 per cent. Other studies show an increase in winter temperatures (García-Herrera et al., 2007). Both changes induce a trend towards a semitropical climate type. Quercus ilex is a typical Mediterranean species adapted to intense variability in temperature and rainfall, variability that had been detected in the area for millennia (Blanco et al., 1997). This physiological adaptation to a Mediterranean climate forces the Holm Oak to a bi-modal growth behaviour in response to climate. Nevertheless, autumn growth is less relevant in the total ring formation than the spring growth. If the climate in Extremadura is changing towards a semi-tropical twoseason model with a decrease of spring rainfall and increase in winter temperatures, the effect over the Holm Oak growth is uncertain. The intense Mediterranean forest decrease experienced during the last decades could be linked to these climatic incidences.

\section{ACKNOWLEDGEMENTS}

We wish show our gratitude to the persons that help in the acquisition of trunk sections of Holm Oaks in special to Maderas Bautista from Alcántara area. Special mention must be for D. Justo Hernández Morgado from Roca de la Sierra (Badajoz) who gave the total set of trunks used from this area. Thanks to Troy Nahumko and Adrian Birtwistle for their support on the English version. 
We also thank two anonymous referees that help during the initial version of the manuscript. R. García-Herrera is partially supported by the EU CIRCE project (EU IP 036961). D. Patón was supported by a "Salvador de Madariaga" grant of the Spanish Minister of Science and Technology. The Spanish National Institute of Meteorology kindly provided the meteorological data.

\section{REFERENCES}

Blanco E, Casado MA, Costa M, Escribano R, García M, Génova M, Gómez A, Gómez F, Moreno JC, Morla C, Regato P and Sáinz H, 1997. Los bosques ibéricos: una interpretación geobotánica (Iberians Forests: an geobotanical interpretation). Madrid, Planeta: 597 pp (in Spanish).

Cañellas I, Roig S, Poblaciones MJ, Gea-Izquierdo G and Olea L, 2007. An approach to acorn production in Iberian dehesas. AgroForestry Systems 70: 3-9, DOI 10.1007/s10457-007-9034-0.

Caritat A, Molinas M and Gutiérrez E, 1996. Annual cork-ring width variability of Quercus suber L. in relation to temperature and precipitation (Extremadura, southwestern Spain). Forest Ecology Management 86: 113-120, DOI 10.1016/S0378-1127(96)03787-5.

Caritat A, Gutiérrez E and Molinas M, 2000. Influence of weather on cork-ring width. Tree Physiology 20: 893-900, DOI 10.1093/treephys/20.13.893.

Carrer $\mathrm{M}$ and Urbinati C, 2001. Assessing climate-growth relationships: a comparative study between linear and non-linear methods. Dendrochronologia 19(1): 57-65.

Cherubini P, Gartner BL, Tognetti R, Braker OU, Schoch W and Innes $\mathrm{JL}, 2003$. Identification, measurement and interpretation of tree rings in woody species from mediterranean climates. Biological Reviews 78: 119-148, DOI 10.1017/S1464793102006000.

Cook ER, 1985. A time series analysis approach to tree-ring standardisation. Ph.D., The University of Arizona, Tucson, Arizona: $183 \mathrm{pp}$.

Cook ER and Kairiukstis LA, 1990. Methods of Dendrochronology. Applications in the Environmental Sciences. Dordrecht, Kluwer Academic: $394 \mathrm{pp}$.

Corcuera L, Camarero JL and Gil-Pelegrín E, 2004. Effects of a severe drought on Quercus ilex radial growth and xylem anatomy. Trees 18: 83-92, DOI 10.1007/s00468-003-0284-9.

Costa A, Pereira H and Oliveira A, 2001. A dendroclimatological approach to diameter growth in adult cork-oak trees under production. Trees 15: 438-443, DOI 10.1007/s004680100119.

Del Rio S, Peñas A and Fraile R, 2004. Analysis of recent climatic variations in Castile and Leon (Spain). Atmospheric Research 73(1-2): 69-85, DOI 10.1016/j.atmosres.2004.06.005.

Fritts HC, 1976. Tree rings and climate. London, Academic Press: $567 \mathrm{pp}$.

García-Herrera R, Luterbacher J, Lionello P, González-Rouco F, Ribera P, Rodo X, Kull C and Zerefos C, 2007. Reconstruction of past Mediterranean climate. $\operatorname{EOS}(88-89): 111$

Glueck MF and Stockton CW, 2001. Reconstruction of the North Atlantic Oscillation, 1429-1983. International Journal of Climatology 21: 1453 .

González F, Merino S, Roldán A, García S and Cuevas JM, 2007. MERIS full resolution data for mapping level-of-damage caused by forest fires: The Valencia de Alcántara event in August 2003. International Journal of Remote Sensing 28 (3-4): 797-809, DOI 10.1080/01431160600979115.

Helama S, Makarenko NG, Karimova LM, Kruglun OA, Timonen M, Holopainen J, Merilainen J and Eronen M, 2009. Dendroclimatic transfer functions revisited: Little Ice Age and Medieval Warm Period summer temperatures reconstructed using artificial neural networks and linear algorithms. Annals of Geophysics 27: 10971111.

Hódar JA, Castro J and Zamora R, 2003. Pine processionary caterpillar Thaumetopoea pityocampa as a new threat for relict Mediterranean Scots pine forests under climatic warming. Biological Conservation 110(1): 123-129, DOI 10.1016/S0006-3207(02)00183-0.

Holmes RL, 1983. Computer-assisted quality control in tree-ring dating and measurement. Tree-Ring Bulletin 43: 68-78.

Le Houérou HN, 1996. Climate change, drought and desertification. Journal of Arid Environment 34: 133-185, DOI 10.1006/jare.1996. 0099.
Lumaret R, Mir C, Michaud H and Raynal V, 2002. Phytogeographical variation of chloroplast DNA in Holm Oak (Quercus ilex L.). Mollecular Ecology 11: 2327-2336.

Luterbacher J, Xoplaki E, Casty C, Wanner H, Pauling A, Küttel M, Rutishauser T, Brönnimann S, Fischer E, Fleitmann D, GonzálezRouco FJ, García-Herrera R, Barriendos M, Rodrigo F, GonzalezHidalgo JC, Saz MA, Gimeno L, Ribera P, Brunet M, Paeth H, Rimbu N, Felis T, Jacobeit J, Dünkeloh A, Zorita E, Guiot J, Türkes M, Alcoforado MJ, Trigo R, Wheeler D, Tett S, Mann ME, Touchan R, Shindell DT, Silenzi S, Montagna P, Camuffo D, Mariotti A, Nanni T, Brunetti M, Maugeri M, Zerefos Ch, De Zolt $\mathrm{S}$ and Lionello P, 2006. Mediterranean climate variability over the last centuries: A review. In: Lionello P, Malanotte-Rizzoli P, Boscolo R, Eds., The Mediterranean Climate: an overview of the main characteristics and issue. Amsterdam, Elsevier: 27-148.

Martín J, Cabezas J, Buyolo T and Patón D, 2005. The relationship between Cerambyx spp. damage and subsequent Biscogniauxia mediterranum infection on Quercus suber forests. Forest Ecology and Management 216: 166-174, DOI 10.1016/j.foreco.2005.05. 027.

Martínez-Vilalta J, Prat E, Oliveras I and Piñol J, 2002. Hydraulic properties of roots and stems of nine woody species from a holm oak forest in NE Spain. Oecologia 133: 19-29, DOI 10.1007/s00442-002-1009-2.

Meehl GA, Stocker TF, Collins WD, Friedlingstein P, Gaye AT, Gregory JM, Kitoh A, Knutti R, Murphy JM, Noda A, Raper SCB, Watterson IG, Weaver AJ and Zhao ZC, 2007. Global Climate Projections. In: Solomon S, Qin D, Manning M, Chen Z, Marquis M, Averyt KB, Tignor M, Miller HL, Eds., Climate Change 2007. The Physical Science Basis. Contribution of Working Group I to the Fourth Assessment Report of the Intergovernmental Panel on Climate Change. Cambridge University Press, Cambridge, New York: $747-845$ pp.

Meko D, Stockton CW and Bogess WR, 1995. The tree-ring record of severe sustained drought. Water Research Bulletin 31: 789-801.

Moreno $G$ and Cubera E, 2008. Impact of stand density on water status and leaf gas exchange in Quercus ilex. Forest Ecology and Management 254: 74-84, DOI 10.1016/j.foreco.2007.07.029.

Nabais C, Freitas H and Hagemeyer J, 1998-1999. Tree rings to climate relationships of Quercus ilex L. in NE-Portugal. Dendrochronologia 16-17: 37-44.

Nardini A, Salleo S, Lo Gullo MA and Pitt F, 2000. Different responses to drought and freeze stress of Quercus ilex L. growing along a latitudinal gradient. Plant Ecology 148: 139-147, DOI 10.1023/A:1009840203569.

Ogaya R, Peñuelas J, Martínez-Vilalta J and Mangirón M, 2003. Effect of drought on diameter increment of Quercus ilex, Phillyrea latifolia and Arbutus unedo in a Holm Oak forest of NE Spain. Forest Ecology and Management 180: 175-184, DOI 10.1016/S03781127(02)00598-4.

Olea L and San Miguel A, 2006. The Spanish dehesa. A traditional Mediterranean silvopastoral system linking production and nature conservation. 21st General Meeting of the European Grassland Federation. Opening Paper, Badajoz: $15 \mathrm{pp}$.

Panaïtois C, Carcaillet C and M'Hamedi M, 1997. Determination of the natural mortality age of a Holm Oak (Quercus ilex L.) stand in Corsica (Mediterranean Island). Acta Oecologie 18: 519-530.

Pañuelas J, Filella I, Lluisà J, Piñol J and Siscart D, 2000. Effects of a severe drought on water and nitrogen use by Quercus ilex and Phillyrea latifolia. Biologia Plantarum 43: 47-53, DOI 10.1023/A: 1026546828466.

Pañuelas J, Lloret F and Montoya R, 2001. Severe drought effects on Mediterranean woody flora of Spain. Forest Science 47: 214-218.

Paredes D, Trigo RM, García R and Franco I, 2006. Understanding precipitation changes in Iberia in Early Spring: Weather typing and storm tracking approaches. Journal of Hydrology 7: 101-114.

Patón D, Zaballos T, Valle M, Rota A, Rojas A, Martín L and Tovar J, 1993. Cálculo de la carga ganadera maxima por métodos dendrocronológicos en matorrales de Cistus ladanifer (Calculation of stocking density maxima by dendrochronological methods in Cistus ladanifer scrub). Archivos de Zootecnia 42: 415-428.

Patón D, Azócar P and Tovar J, 1998. Growth and productivity in forage biomass in relation to the age assessed by dendrochronology in the evergreen shrub Cistus ladanifer (L.) using different regression models. Journal of Arid Environments 38: 221-235.

Patón D, Nuñez J, Díaz MåA and Muñoz A, 1999. Assessment of browsing biomass, nutritive value and carrying capacity of shrub- 
lands for red deer (Cervus elaphus L.) management in Monfragüe Natural Park (SW Spain). Journal of Arid Environments 42: 137147, DOI 10.1006/jare.1999.0501.

Patón D, Galavis M, Venegas F and Roig F, 2006a. Comparative relationships between rainfall and radial growth assessed by dendrochronology in Pinus pinea L. and Pinus pinaster Aiton Cast. from high Tiétar river valley (Avila, Spain). In: First MedCLIVAR Workshop on Reconstruction of Past Mediterranean Climate: $60 \mathrm{pp}$.

Patón D, Venegas F, Galavis M and Roig F, 2006b. Relationships between rainfall and radial growth assessed by dendrochronology in holm-oak (Quercus rotundifolia Lam.) from "Valencia de Alcántara" (Cáceres, SW Spain). In: First MedCLIVAR Workshop on Reconstruction of Past Mediterranean Climate: 59 pp.

Patón D, Venegas F, Cuenca J, Galavis M and Roig F, 2006c. The swet chesnut (Castanea sativa Miller) forest of Montánchez (Cáceres, SW Spain). An announced dessaparition by climatic causes? In: First MedCLIVAR Workshop on Reconstruction of Past Mediterranean Climate: $61 \mathrm{pp}$.

Plieninger T, Pulido FJ and Schaich H, 2004. Effects of land-use and landscape structure on Holm Oak recruitment and regeneration at farm level in Quercus ilex L. dehesas. Journal of Arid Environments 57: 345-364, DOI 10.1016/S0140-1963(03)00103-4.

Puigdefábregas J and Mendizábal T, 1998. Perspectives on desertification: western Mediterranean. Journal of Arid Environments 39: 209-224, DOI 10.1006/jare.1998.0401.

Puerto A and Rico M, 1989. Influence of tree canopy (Quercus rotundifolia Lam.) on content in surface soil water in Mediterranean grasslands. Ecology 8(3): 225-238.

Pulido FJ, Díaz M and Hidalgo S, 2001. Size structure and regeneration of Spanish Holm Oak Quercus ilex forests and dehesas: effects of agroforestry use on their long-term sustainability. Forest Ecology and Management 146(1-3):1-13.

$\mathrm{R}$ Development Core Team, 2003. R Installation and administration. GNU Free Software Foundation, Boston, Massachusetts.

Roig F, Barriopedro D, García R, Patón D and Monge S, 2006. NAO signatures in SouthWestern Iberian tree rings. In: First MedCLIVAR Workshop on Reconstruction of Past Mediterranean Climate: $32 \mathrm{pp}$.

Rodríguez MC, Blanco A, Palo EJ, Torres LM, Torres E and Suárez MA, 2005. Seasonal and spatial mortality patterns of holm oak seedlings in a reforested soil infected with Phytophthora cinnamomi. Forest Pathology 35(6): 411-422.

Rodríguez MC, Santiago R, Blanco A, Pozo JD, Colino M, Palo EJ and Torres LM, 2003. Detección de Phytophthora cinnamomi en dehesas de Extremadura afectadas por "seca" y su comportamiento in vitro (Detection of Phytophthora cinnamomi in pastures of Extremadura affected by "dry" and their behavior in vitro). Boletin de Sanidad Vegetal (Plagas) 29: 625-638 (in Spanish).

Saenz C, 1967. Estudios sobre Quercus ilex L. y Quercus rotundifolia Lamk (Studies on Quercus ilex L. and Quercus rotundifolia Lamk.). Anales del Instituto de Botánica Cavanilles 2: 243-262 (in Spanish).

Serrano A, Mateos VL and García JA, 1998. Trend analysis of monthly precipitation over the Iberian Peninsula for the Period 1921-1995. Physics and Chemistry of the Earth 24(1-2): 85-90.

Serre-Bachet F, Guiot J and Tessier L, 1992. Dendroclimatic evidence from southwestern Europe and northwestern Africa. In: Bradley RS, Jones PD ,eds, Climate since AD 1500. Routledge, London, pp. $165-178$.

Tardif JC and Conciatori F, 2006. A comparison of ring-width and event-year chronologies derived from White Oak (Quercus alba) and Northern Red Oak (Quercus rubra) southwestern Quebec, Canada. Dendrochronologia 23: 133-138, DOI 10.1016/j.dendro. 2005.10.001.

Terradas J, 1999. Holm Oak and Holm Oak forests: an introduction. In: Rodà F, Retana J, Gracia CA, Bellot J, Eds., Ecology of Mediterranean Evergreen Oak Forests. Springer-Verlag, Berlin: 3-14.

Terradas J and Savé R, 1992. The influence of summer and winter stress and water relationships on the distribution of Quercus ilex L. Vegetatio 99-100: 137-145.

Touchan R and Hughes MK, 1999. Dendrochronology in Jordan. Journal of Arid Environments 42: 291-303, DOI 10.1006/ jare.1999.0507.

Trigo $\mathrm{R}$ and 21 coauthors, 2006. Relations between variabilityin the Mediterranean region and Mid-latitude variability. In: Lionello P, Malanotte-Rizzoli P, Boscolo R, Eds., The Mediterranean Climate: an overview of the main characteristics and issues. Elsevier, Amsterdam, pp. 179-226.

Tutin TG, Heywood VH, Burges NA, Moore DM, Valentine DH, Walters SM, Webb DA, 1993. Flora Europaea. Cambridge University Press, London: 1235 pp.

Villar P, Castro P, Pérez C and Montserrat G, 1997. Stem xylem features in three Quercus (Fagaceae) species along a climatic gradient in NE Spain. Trees 12: 90-96, DOI 10.1007/PL00009701.

Wigley TML, Briffa KR and Jones PD, 1984. On the average value of correlated time series, with applications in dendroclimatology and hydrometeorology. Journal of Climate and Applied Meteorology 23: 201-213.

Zhang SH and Romane F, 1991. Variations de la croissance radiale de Quercus ilex L. en fonction du climat (Variations of the radial growth of Quercus ilex L. depending on the climate). Annals of Forest Science 48: 225-234 (in French). 